\title{
Dinamika Kesetaraan Gender di Arab Saudi: Sebuah Harapan Baru di Era Raja
} Salman

\author{
Nevy Rusmarina Dewi", Azza Ihsanul Fikri, Afifah Febriani \\ nevyrusmarina@iainkudus.ac.id, azzaihsanulfikri@gmail.com, afifahfeb550@gmail.com \\ ${ }^{123}$ Program Studi Pemikiran Politik Islam, Institut Agama Islam Negeri (IAIN) Kudus
}

\begin{abstract}
Saudi Arabia is one of the Moslem countries in the Middle East which limits women's rights. These women have limited access to economy, education, as well as politics. 2009 was the milestone for women's public participation in Saudi Arabia. This research aims to analyze the development of gender equality issue in Saudi Arabia which encourages policy changes in the era of King Salman. Gender is a character owned by someone in accordance with his/her social role based on his/her sex. Gender equality focuses on the equality of social role which is obtained by both men and women. In Koran surah Al- Baqarah article 288, there are two perspectives about women's position which included normative and contextual aspects. Gender equality in Islamic's perspective has been recognized in OKI's Charter article 6. This research uses qualitative method with literature study approach. The result shows that the dynamic of policy changes in Saudi Arabia is influenced by the condition of Saudi's women socio-cultural itself, the debate of the Ulama about gender equality which proposes Wassatiya's perspective and Vision 2030 by Mohammad bin Salman as the hope of the implementation of the policy which gives a bigger opportunity for women's role in public.
\end{abstract}

Keywords: gender, Islam, Salman, Saudi Arabia, woman.

\begin{abstract}
Abstrak
Arab Saudi merupakan salah satu negara Islam di Timur Tengah yang selama ini membatasi hak-hak wanita. Wanita dibatasi dalam bidang ekonomi, pendidikan, maupun politik. Tahun 2009 tonggak dari keterlibatan wanita pada bidang publik di Arab Saudi. Penelitian ini bertujuan untuk menganalisis perkembangan wacana kesetaraan gender di Arab Saudi yang mendorong terjadinya perubahan kebijakan di era Raja Salman. Gender ialah karakter yang dimiliki seseorang sesuai dengan peran sosial yang lingkungan berikan sesuai dengan jenis kelaminnya. Kesetaraan gender sendiri memfokuskan pada kesetaraan peran sosial yang didapatkan baik oleh laki-laki maupun perempuan. Dalam Qur'an surat $\mathrm{Al}$ Baqarah ayat 228 terdapat dua pandangan mengenai kedudukan perempuan meliputi aspek normatif dan konstektual. Kesetaraan gender dalam perspektif Islam telah diakui dalam Piagam negara OKI pada Pasal 6. Metode penelitian yang digunakan adalah kualitatif dengan pendekatan studi literatur. Hasil penelitian menunjukkan bahwa dinamika perubahan kebijakan di Arab Saudi dipengaruhi oleh kondisi sosial-budaya perempuan Arab, perdebatan para ulama tentang kesetaraan gender yang mengemukakan sudut pandang Wassathiya, dan program Visi 2030 oleh Pangeran Mohammad bin Salman sebagai harapan penerapan kebijakan yang memberikan ruang lebih besar bagi peran perempuan di ruang publik.
\end{abstract}

Kata kunci: Arab Saudi, gender, Islam, perempuan, Salman.

\section{Pendahuluan}

Arab Saudi adalah tanah bagi dua kota suci Islam. Sejak melepaskan diri dari Kerajaan Ottoman, Arab Saudi menjadi kekuatan besar di kawasan Timur Tengah dengan sumber daya minyaknya yang melimpah yang dimanfaatkan dengan baik dan kekuatan militernya yang besar dengan anggaran belanja impor senjata terbesar di dunia (USD 6,46 Milyar)(statistica, n.d.). Meskipun menjadi kekuatan besar di kawasan tersebut, kritikan muncul terhadap sistem hukum yang Arab Saudi gunakan yaitu hukum syariat Islam. Hukum syariat Islam yang dianut Arab Saudi ini didasarkan paham salafus shalih dan bermazhab Hambali (Ardiansyah, 2013).

\footnotetext{
* Corresponding Author: Nevy Rusmarina Dewi. Program Studi Pemikiran Politik Islam, Institut Agama Islam Negeri (IAIN) Kudus. Jl. Conge Ngembalrejo 51 Kudus 59322.
} 
Penerapan hukum syariat Islam di Arab Saudi yang menurut Barat cukup kontroversial adalah hukuman mati dengan sistem pancung. Gerak perempuan di Arab Saudi cukup dibatasi dengan pelarangan wanita berpergian sendirian dan pelarangan untuk mengemudi mobil, bahkan pada tahun 2013 ada 16 perempuan pengikut gerakan kampanye mengemudi dinyatakan bersalah dan mendapat denda sebesar 300 Riyal (Republika, 2013).

Dalam konteks pendidikan, Arab Saudi menggunakan kurikulum yang berbasis agama. Bagi masyarakat Arab Saudi, pendidikan bisa dikatakan berhasil apabila kita bisa menerapkan nilai-nilai Islam pada kehidupan kita. Dalam pemilihan program studi, Arab Saudi membedakan peran antara laki-laki dan perempuan. Dimana untuk laki-laki hanya bisa memilih program studi yang sesuai dengan perannya, misalnya program studi yang berkaitan dengan maskulinitas yaitu seperti ilmu sains dan teknologi. Sedangkan untuk perempuan hanya bisa memilih program studi yang berkaitan dengan ilmu keguruan, sastra, dan ilmu kesehatan (Alwedinani, 2016). Pembedaan peran dalam pemilihan program studi inilah yang mengakibatkan program studi mereka seringkali tidak sesuai dengan minat dan bakat. Dengan adanya pembatasan dalam pemilihan program studi ini timbulah rasa ketidak adilan bagi perempuan dan laki-laki. Bagi kaum perempuan dari kelas menengah atas, jika ingin melanjutkan pendidikan sesuai bakat dan minat mereka akan mencari perguruan tinggi di luar negeri, sedang bagi yang kurang mampu mereka terpaksa mengambil pendidikan di dalam negeri sesuai dengan ketentuan yang berlaku (Alwedinani, 2016).

Dalam konteks sosial, di Arab Saudi gerak perempuan yang berkarir cukup dibatasi dengan adanya pelarangan perempuan berpergian sendirian dan pelarangan untuk mengemudikan mobil, hal inilah yang akan mempersulit mobilitas mereka. Perempuan juga tidak diijinkan berpergian ke luar negeri tanpa izin wali laki - laki. Sedangkan dalam konteks politik, Arab Saudi sangat membatasi peran perempuan untuk berpartisipasi dalam ranah perpolitikan. Perempuan boleh berpartisipasi dalam politik ketika ada pemilu apabila pemilu itu dilaksanakan di negaranya sendiri, seperti contohnya pemilihan kota, dan itupun harus ada wali mereka yang mau berpartisipasi dengan membawa perempuan ke bilik suara.

Pada bulan Februari 2009 Raja Abdullah menunjuk seorang perempuan Noura AlFayez untuk diangkat sebagai Wakil Menteri Pendidikan masalah perempuan (Faktualnews, 2020). Pengangkatan Noura Al-Fayez sebagai Wakil Menteri Pendidikan memicu munculnya gerakan-gerakan yang menuntut hak-hak perempuan. Gerakan-gerakan yang muncul bersifat perorangan dan bukan asosiasi karena adanya pembatasan organisasi sipil secara ketat di Arab Saudi. Pengangkatan perempuan sebagai Wakil Menteri Pendidikan Arab Saudi menunjukkan bahwa Raja Arab Saudi mendukung perubahan tentang peran perempuan. Namun perjuangan hak-hak perempuan di Arab Saudi masih terhalang oleh tokoh-tokoh agama yang konservatif. Pengaruh tokoh agama yang konservatif ini cukup kuat sehingga memicu penolakan terhadap kebijakan yang membolehkan keterlibatan perempuan dalam sektor-sektor baru di publik Arab Saudi. Walaupun ada penolakan dari golongan konservatif, pemerintah Arab Saudi tetap mengesahkan kebijakan yang menghapus pembatasan hak-hak perempuan, seperti penghapusan aturan yang tidak membolehkan perempuan menyetir mobil. Penerapan kebijakan pemerintah Arab Saudi yang cenderung membatasi perempuan di ruang publik menjadi sorotan masyarakat internasional ditinjau dari perkembangan studi gender. 


\section{Kesetaraan Gender Dalam Tinjauan Berbagai Perspektif}

Gender menurut WHO (2001) merupakan perbedaan status dan peran yang dibentuk oleh masyarakat berdasarkan nilai budaya yang berlaku sebagai perempuan dan laki-laki. Kesetaraan gender telah menjadi rezim dalam dunia internasional yang telah menjadi ranah PBB. Hal ini karena kesetaraan gender merupakan representasi dari kondisi dalam mencapai hak yang sama antara laki-laki dan perempuan mulai dari lingkup keluarga, negara, bahkan internasional.

Organisasi Persatuan Bangsa-Bangsa (PBB) pada tahun 1979 mengadopsi konvensi yang berisi penghapusan diskriminasi terhadap perempuan dalam Convention on the Elimination of All Forms of Discrimination against Women (CEDAW). CEDAW menjadi dasar bagi kesetaraan perempuan dengan laki - laki dalam hal kesempatan kehidupan politik, publik, pendidikan, kesehatan serta pekerjaan (Qodarsasi, 2014). Dukungan banyak negara melalui ratifikasi konvensi tersebut untuk mengukuhkan penghapusan diskriminasi terhadap perempuan.

Dalam perspektif Islam Al Qur'an menekankan dua pandangan mengenai kedudukan perempuan. Pertama, pandangan yang menjunjung tinggi kesetaraan antara laki-laki dan perempuan, dan kedua, pandangan yang menunjukkan adanya superioritas laki-laki atas perempuan. Dengan izin Allah, laki-laki memiliki sedikit superioritas di atas perempuan agar Islam dapat diterima dengan baik. Hal ini dapat ditemukan dalam Surat Al Baqarah ayat 228. Dalam ayat ini ada dua pandangan mengenai kedudukan perempuan. Dua pandangan itu tercermin dalam dua aspek yang digunakan dalam memahami Al Qur'an yaitu aspek normatif dan konstektual. Dalam aspek normatif Al Qur'an, kesetaraan gender dapat ditemukan dalam pernyataan "hak yang seimbang". Aspek normatif disini berarti bahwa aspek yang terdapat dalam Al Qur'an ini bisa diterapkan di masa apapun karena bersifat eternal. Selanjutnya dalam aspek konstektualnya bisa ditemukan dalam pernyataan "Suami satu tingkat di atas istri." Aspek konstektual disini berarti bahwa aspek yang terdapat dalam Al Qur'an ini berkaitan dengan masalah-masalah yang terjadi pada masa itu dan bagaimana Al Qur'an merespon masalah tersebut. Menurut Engineer dalam Nuryatno, dicakupkannya dua aspek tersebut dalam satu ayat dimaksudkan agar ayat tersebut dapat diterima oleh masyarakat di mana ayat tersebut diturunkan dan sekaligus bisa diterapkan di masa yang akan datang ketika situasi sosial sudah berubah dan lebih kondusif (Nuryatno, 2001).

Menurut Amina Wadud, antara laki-laki dan perempuan memiliki nilai yang secara inheren sama sebagai manusia. Menurutnya terjadi kesetaraan yang meliputi beberapa hal, antara lain yaitu; pertama, didalam Al-Qur'an disebutkan bahwa penciptaan manusia seluruh umat manusia berasal dari kesatuan yang sama, kedua di dalam Al-Qur'an ditegaskan mengenai potensi untuk berkembang, tumbuh, dan berubah ada dalam nafs individu ataupun kelompok; ketiga, balasan kepada manusia diberikan sesuai apa yang telah diupayakan (Wadud, 2006, p. 68). Bahkan menurut Ahmad Musthofa al- Maraghi apa yang tercantum dalam Q.S. Ali Imron ayat 195, kesimpulannya mengenai kedudukan laki-laki dan wanita dalam hal pembalasan Allah semua sama nilainya di hadapan Allah (Zilfa, 2017, p. 6).

Menurut Nasaruddin Umar, kesetaraan gender ada di dalam Al-Qur'an, hanya saja dalam pelaksanaannya terjadi ketidakadilan dengan menggunakan dalih agama, dimana ada kesalahan interpretasi sikap dan perilaku individu yang sudah terlanjur mengakar menjadi tradisi patriarki dalam budaya masyarakat. Menurutnya prinsip-prinsip kesetaraan gender ada di dalam Al-Qur'an, yang pertama persamaan kedudukan sebagai hamba menurut QS. Al-Dzariyat (51): 
56, kedua sebagai khalifah di bumi tidak disebutkan secara spesifik secara khusus sehingga semua punya peran sama dalam QS. al-An'am (6): 165, dan dalam QS. al-Baqarah (2): 30, ketiga Perempuan dan laki-laki sama-sama mengemban amanah dan menerima perjanjian awal dengan Tuhan, seperti dalam QS. al-A'raf (7): 172 (Maslamah \& Muzani, 2014). Bahkan, kesetaraan gender dalam perspektif Islam telah diakui dalam Piagam negara OKI pada Pasal 6 yang berisi tentang kesamaan derajat antara laki-laki dan perempuan dalam menikmati hidup sesuai tugas dan penampilannya sebagai wanita baik dalam mencari ilmu, kesempatan kerja, maupun hak menjaga nama baiknya (Maslamah \& Muzani, 2014). Dengan demikian, tulisan ini tertarik untuk menjelaskan dinamika perubahan kebijakan pemerintah Arab Saudi yang memungkinkan adanya dukungan terhadap kesetaraan gender dalam negara Islam.

\section{Metode}

Penelitian ini mengaplikasikan metode kualitatif yang berfokus pada proses eksplorasi dalam rangka memahami perilaku individu serta kelompok sehingga didapatkan gambaran yang jelas dalam memahami masalah sosial (Creswell, 2012). Hal ini merujuk pada perilaku pemerintah Arab Saudi dengan kebijakan yang mendukung kesetaraan gender sebagai objek penelitian. teknik pengumpulan data berbasis studi literatur. Kunci utama dari model pendekatan ini adalah dengan studi kasus maka akan memungkinkan untuk mendapatkan wawasan yang mendalam dari proses peristiwa atau suatu situasi yang terjadi melalui penyelidikan suatu peristiwa, situasi, atau kondisi tertentu (Hodgett \& Stolte, 2012). Data yang digunakan bersumber dari dokumen yang berupa buku, artikel jurnal, artikel surat kabar, hasil survey, baik fisik maupun daring yang berhubungan dengan topik penelitian.

\section{Hasil dan Pembahasan}

\section{Faktor Sosial-Budaya Arab Saudi Dalam Memahami Peran Perempuan}

Sebagian besar warga negara kawasan Arab Saudi masih meyakini bahwa tugas utama seorang perempuan adalah berada di dalam rumah. Arab Saudi mempunyai undang-undang yang mengatur bahwa perempuan Arab Saudi harus mendapatkan izin dari wali laki-laki mereka dalam melakukan berbagai kegiatan di kehidupan sehari-harinya. Dalam kehidupan berkeluarga, seorang laki-laki dan perempuan mempunyai tingkatan yang berbeda, laki-laki bertugas untuk mencari nafkah untuk keluarga sedangkan perempuan hanya boleh merawat anak-anaknya di rumah. Di Arab Saudi, perempuan tidak boleh meninggalkan rumahnya tanpa persetujuan dari seorang wali laki-laki. Seorang laki-laki juga harus bisa mengatur dan mengendalikan kebebasan istrinya. Kebebasan itu sendiri dalam bentuk cara berpakaian, sampai dengan tingkah laku istrinya (Lilolia, 2019). Hal semacam inilah perempuan merasakan adanya ketidakadilan dalam berumah tangga dan dirasa adanya pemasungan terhadap kebebasan perempuan.

Ada pula teologi yang membahas tentang pembebasan, dimana persamaan dan keadilan distributif dan secara vokal mengutuk eksploitasi manusia oleh manusia, penindasan dan persekusi dan segala hal yang berbentuk simpati kepada yang tertindas dan lemah dan membuat ruang bagi peninggian derajat mereka lewat formulasi-formulasi teologis. Di samping perhatian terhadap masalah kebebasan dan persamaan, teologi kebebasan ini juga digunakan untuk mengemansipasi mereka yang tertindas dengan cara memberikan bekal tentang kesadaran kritis atas realitas disekitar mereka lewat formulasi teologis. Selain itu, teologi kebebasan ini juga 
bermaksud untuk menciptakan struktur baru non eksploitatif dan berkeadilan. Hal ini bertujuan untuk meningkatkan derajat manusia (Nuryatno, 2001). Padahal pada dasarnya perempuan juga berhak memilih, menjalani, dan menikmati hidup selayaknya, dan tentunya sebagai manusia yang bebas dan merdeka. Tetapi, di sisi lain apabila seorang perempuan diberi kesempatan untuk berkuasa, maka ditakutkan kalau mereka berperilaku seperti kaum laki-laki.

Dengan masih adanya keyakinan yang seperti ini berarti dapat disimpulkan bahwa faktor Arab Saudi tidak pro dengan kesetaraan gender itu dikarenakan warga negara Arab Saudi masih kurang sadar akan pemahaman tentang kesetaraan gender. Faktor lain yang memicu Arab Saudi tidak pro kesetaraan gender yaitu dapat dilihat dari jumlah kekerasan dan diskriminasi terhadap perempuan yang sering ditemukan di Arab Saudi terus meningkat tiap tahunnya. Diskriminasi yang terjadi di Arab Saudi itu sendiri dapat dilihat dari tidak adanya respon aturan yang mendukung bahwa perempuan itu sangat berperan dalam keluarga dan masyarakat. Di Arab Saudi hak perempuan sangat dihalangi untuk bisa memutuskan kehidupannya sendiri. Dewan Senior Ulama Negara, pada tanggal 7 November 1990 mengeluarkan fatwa pelarangan bagi perempuan untuk mengemudikan mobil dengan alasan bahwa perempuan rentan melepas jilbab yang mereka kenakan ketika sedang mengemudi (Republika, 2013). Para perempuan di Arab Saudi jika ingin berpergian harus diantar oleh wali mereka, baik ayah, kakek, kakak laki-laki, adik laki - laki ataupun anak laki-laki namun jika mereka berhalangan untuk mengantar maka mereka harus menggunakan transportasi lokal seperti taxi atau uber (Alwedinani, 2016).

Berdasarkan data Gender Inequality Index (GII) 2018 di kawasan Timur Tengah, Arab Saudi memiliki tingkat Gender Inequality Index 0.224, sedangkan di Suriah tingkat GII 0.547 sedangkan di negara Arab secara umum 0.531(UNDP, 2019). Data tersebut menunjukkan bahwa angka GII Arab Saudi lebih rendah daripada negara di Timur Tengah lainnya. Semakin rendah angka GII maka ketidaksetaraan gender semakin rendah, begitu juga sebaliknya. Index ketidaksetaraan gender memperlihatkan bahwa terjadi ketidaksetaraan gender yang terdiri dari tiga dimensi yaitu kesehatan reproduksi, pemberdayaan, serta partisipasi di pasar tenaga kerja sehingga menjadi tolak ukur pelaksanaan gender di Arab Saudi lebih baik dibandingkan negara lain di wilayah Timur Tengah.

Pemerintah Arab Saudi tidak setuju dengan adanya kesetaraan gender karena definisi gender di Arab Saudi itu sebagai pembedaan peran antara laki-laki dan perempuan yang dimana itu merupakan hasil dari sosial budaya yang memiliki sifat tidak tetap, serta peran antara laki-laki dan perempuan bisa ditukar menurut waktu, tempat, dari jenis kelamin yang satu dengan jenis kelamin yang lainnya. Dari sinilah adanya pertentangan antara konsep Islam dan arti kesetaraan gender di Arab Saudi. Bahwa menurut konsep Islam, tugas laki-laki dan perempuan didasari menurut wahyu Allah. Dalam Al-quran dan Sunnah dijelaskan, tanggung jawab laki-laki itu sebagai kepala keluarga dan mencari nafkah. Apabila tugas utama seorang laki-laki dan perempuan yang berdasar atas wahyu Allah itu dirombak, maka secara otomatis konsep tersebut akan membangkang tindakan yang dianjurkan oleh Allah SWT. Selain itu juga dirasa penyamaan peran tersebut akan bisa menyaingi Allah SWT dalam pembuatan hukum.

Dalam konteks peran berbasis gender, pemerintah Arab Saudi khawatir apabila warga negara mengadopsi pemikiran Barat di mana perjuangan pengarusutamaan gender hanya bersifat simbolik berdasarkan trauma praktik kolonialisme Abad Pertengahan. Pemerintah berupaya mencegah sikap yang berlebihan dalam memaknai kesetaraan gender ala Barat di mana kebebasan 
perempuan cenderung menjadi problematika social jika diterapkan dalam kultur masyarakat Arab. Berdasarkan konteks sosial-budaya Arab Saudi, perempuan yang telah berkeluarga dikatakan berhasil apabila ia mampu merawat dan mengurus rumah tangga mereka. Namun jika kaum perempuan juga turut bekerja mencari nafkah dan mengejar karirnya, dikhawatirkan di masa yang akan datang hal ini akan mendorong perempuan mengambil alih semua tugas laki-laki, dan berujung pada persaingan di dalam berbagai bidang. Hal tersebut akan mencederai martabat perempuan Arab Saudi dan mengubah identitas normatif perempuan Arab pada umumnya.

\section{Perbedaan Pendapat Ulama Tentang Kesetaraan Gender}

Kerajaan Arab Saudi didirikan pada tahun 1175 H/1744 M oleh oleh Imam Muhammad bin Saud di "Ad-Dir'iyah" di sebelah barat Kota Riyadh yang meliputi hampir semua jazirah arab. Hukum dasar yang digunakan adalah ajaran para Salaf Shalih menuju kemurnian tauhid kepada Allah untuk mencegah perilaku bid'ah dan khufarat. Periode negara Saudi dimulai tahun 1240 H/1824 M ketika Imam Faisal bin Turki mengubah kerajaan dengan mendirikan negara. Pada tahun 1932 Raja Abdul Aziz berhasil menyatukan seluruh wilayahnya yang luas ke dalam sebuah negara modern yang kuat yang dikenal dengan nama Kerajaan Arab Saudi sebagai fase baru Arab modern dengan menggunakan kaidah pokok dalam Al-Qur'an sebagai Undang-Undang Dasar (Rohim, 2013).

Al-Qur'an sebagai sumber syariah utama, tidak menjelaskan mengenai pelaksanaan pemerintahan, maka sejak Raja Abdul Azis berkuasa mulai banyak diundangkan peraturan yang berfungsi dalam menjalankan pemerintahan. Pada tahun 1992, Raja Fahd berhasil membuat aturan kompilasi pertama di Arab Saudi sebagai hukum dasar pemerintahan yang disebut dengan Nizham Al-Asasi lil Hukmi (basic law). Dalam hirarkhi perundangan di Arab Saudi, hukum tertinggi adalah Al-Qur'an dan Sunnah Rasulullah, di bawahnya adalah Nizham Al-Asasi lil Hukmi (basic law), selanjutnya undang-undang baru kemudian adalah dekrit raja (Rohim, 2013). Dokumen Hukum Dasar berisi 83 pasal dan 9 bagian yang isinya mengatur tentang sistem pemerintahan, hak dan kewajiban pemerintah serta warga negara. Hukum Dasar ini di dalamnya telah memuat jaminan terhadap hak dan kewajiban warga negara, namun belum secara jelas memuat mengenai jaminan kebebasan warga untuk beragama, berekspresi, berkumpul, atau partisipasi politik. Hukum dasar Arab Saudi mengatur bahwa kekuasaan legislatif, berada pada Majlis Al-Shura atau Majelis Permusyawaratan yang anggotanya terdiri dari 150 orang ahli yang ketuanya di tunjuk oleh raja.

Majlis Al-Shura bertugas memberikan nasehat kepada raja serta memberi penilaian, memberikan penafsiran serta memberikan perbaikan pada aturan- aturan berupa undang-undang kerajaan, undang-undang kecil, kontrak, dan perjanjian antarbangsa. Tugas lainnya adalah memberi nasehat kepada Majelis Raja dan Dewan Menteri berkaitan dengan isu-isu serta kebijakan-kebijakan kerajaan (Rohim, 2013). Majlis Al-Shura dapat dibubarkan oleh raja berdasar pasal 68, dan dapat dibentuk oleh raja kembali. Aturan mengenai tugas raja untuk menjalankan peraturan berdasarkan ajaran Islam dan mengawasi aplikasi syariah, peraturan, dan kebijakan negara secara umum, termasuk perlindungan dan pertahanan negara merupakan isi dari pasal 55.

Pasca pengangkatan Deputi Menteri Pendidikan perempuan pertama pada Februari 2009, Saad bin Nasir bin Abd al-Aziz al-Shithri adalah orang pertama yang memicu debat kesetaraan gender di Arab Saudi, karena dianggap menyerang kaum liberal dengan pernyataannya. Al-Shithri 
adalah anggota keluarga ulama terkenal yang telah melayani keluarga kerajaan bahkan ia ditunjuk Dewan Ulama Senior selama perombakan personil Februari 2009. Salah satu fatwanya adalah larangan melakukan jihad tanpa persetujuan penguasa. Selain itu dia juga memberikan pesan peringatan agar tidak menggunakan teks-teks suci dalam rangka pengembangan pemikiran ekstrim yang berujung pada kemurtadan dan terorisme. Syaikh Saad al-Shithri diwawancarai oleh stasiun TV swasta al-Majd pada tanggal 28 September 2009 dimana pada akhir wawancara dia menyebutkan mengenai salah satu alasan menentang sesuatu yang baik yaitu menentang kesetaraan gender yang dianggap sebagai kejahatan besar. Ia menyatakan bahwa di kampus yang campuran gender terjadi kejahatan dimana baik pria ataupun wanita yang saling melihat bisa menimbulkan hati yang terbakar. Hal ini kemudian memicu emosi kaum liberal dan memicu debat dari ulama lainnya (Meijer, n.d.)

Al-Quran menegakkan prinsip persamaan derajat antara laki-laki dan perempuan. Dengan kata lain, kitab suci memberikan perhatian pada persoalan kesetaraan gender (gender equality). Adapun prinsip dasar yang membahas tentang persoalan kesetaraan gender. Prinsip pertama manusia itu diciptakan dari esensi yang sama. Karena berasal dari esensi yang sama, Engineer menolak pandangan bahwa Hawa diciptakan dari tulang rusuk Adam. Prinsip kedua, Tuhan itu memuliakan semua anak Adam, termasuk didalamnya tentu saja laki-laki dan perempuan. Dan yang terakhir, baik laki-laki dan perempuan berhak mendapat pahala dari Tuhan bila melakukan amal kebaikan. Reward dan punishment dari Tuhan tidak membedakan latar belakang jenis kelamin (Nuryatno, 2001). Akan tetapi hal ini berbanding terbalik dengan keadaan yang terjadi di Arab Saudi sebelum adanya kesadaran peningkatan kesetaraan gender.

Salah satu pendukung Wasatiyya (jalan tengah) dan kaum rasionalis, Ahmad bin Qasim al-Ghamidi, memiliki empat ide gagasan reformis yang pada tanggal 9 Desember 2009, menulis sebuah artikel di Okaz yang mendukung kesetaraan gender juga mengatakan bahwa pelarangannya tidak memiliki dasar syariah (Meijer, n.d.). Pertama, menantang kompetensi agama para ulama, menurutnya kesetaraan adalah hal alami dalam kehidupan umat, larangan yang selama ini dimunculkan tanpa bukti agama yang jelas yang hanya didasarkan pada kebiasaan dan tradisi. Kedua menyangkut otoritas ulamamengenai ijtihad yang dianggap memihak dan tanpa bukti penyelidikan yang hanya menerima pendapat ulama senior. Pengambilan keputusan model ini dalam salafi dilarang (Alarabiya, 2010). Al-Ghamidi meminta raja mengakhii ijtihad tersebut karena dianggap mengancam kesatuan umat dan menyebabkan pertikaian.

Ketiga, Al-Ghamidi lebih rasional, berdasarkan pada tren al-Wasatiyya yang memperkuat kaum liberal dimana kesetaraan gender adalah akibat dari kebijakan yang telah mengakar di Arab Saudi selama 30 tahun terakhir sehingga masyarakat berusaha untuk mendapatkan kesamaan hak tanpa ada yang terabaikan. Keempat adalah pragmatis, berdasarkan pengalamannya sebagai kepala Hayaa, penegak larangan pencampuran gender, seorang pria dan wanita dapat bertemu hanya berdua saja melalui webcam tanpa harus berjumpa secara fisik sehingga mereka yang mengutuk pencampuran gender dalam bentuk konvensional sudah ketinggalan zaman karena bentuk interaksi yang selalu berkembang mengikuti perkembangan zaman.

Salah satu ulama konservatif di Arab Saudi yaitu Sheikh Abd al-Rahman al Barrak berusia 77 tahun mengeluarkan fatwa pada 22 Februari 2010 yang isinya memperingatkan kepada kaum liberal untuk tidak mempromosikan kesetaraan gender karena menurutnya kesetaraan antara pria 
dan wanita dalam pekerjaan dan pendidikan adalah haram karena akan menimbulkan tatapan yang mengundang syahwat, apalagi jika harus terjadi pertemuan antara seorang pria dan wanita akan memberikan kemudharatan. Bahkan menurutnya kaum yang mendukung kesetaraan gender adalah orang yang tidak beriman, serta dianggap murtad, sehingga jika mereka tidak bertaubat dapat dibunuh (albarrak, 2010). Hal ini diperkuat dengan pandangan dari Sheikh Yusuf bin Abdallah al-Ahmad profesor di Departemen Syariah di Universitas Islam Imam Muhammad bin Saud di Riyadh mengeluarkan fatwa pada bulan Maret tahun 2010 menyerukan agar Masjidil Haram di Mekah diperbesar untuk mencegah percampuran jenis kelamin. Dia menyatakan bahwa saat Tawwaf tidak mengijinkan istrinya ataupun kerabat lainnya untuk bersentuhan dengan lawan jenis sehingga menyarankan untuk memperluas Masjidil Haram dari 900,000 menjadi 10 juta orang (Meijer, n.d.).

\section{Harapan Baru Penerapan Kesetaraan Gender di Era Raja Salman}

Pada tahun 2015 Raja Salman naik tahta menggantikan Raja Abdullah. Selanjutnya mengambil kebijakan dengan memilih Mohammad bin Salman sebagai putra mahkota. Pada periode ini mulai banyak perubahan yang tejadi, salah satunya ketika mulai menjabat sebagai putra mahkota, Mohammad bin Salman melakukan reformasi kebijakan salah satunya yaitu kebijakan Visi 2030 Saudi Arabia untuk meningkatkan perekonomian Arab Saudi. Kebijakan ini dijalankan dengan cara membuka kesempatan yang sama dalam pekerjaan antara laki - laki dan perempuan (Kompas, 2019).

Dalam perspektif islam wasathiyah, setiap muslim saling berhubungan dengan Allah dan menciptakan masyarakat yang adil. Meskipun perempuan adalah salah satu komponen dalam hubungan antar sesama manusia, perempuan sering diperlakukan sebagai masyarakat kelas dua. Dalam Forum Ekonomi Dunia 2014 tentang kesenjangan gender menunjukkan bahwa sebagian besar negara mayoritas muslim memiliki kesenjangan terbesar dalam hal memajukan perempuan dalam hal bidang kesehatan, pendidikan, politik dan ekonomi (Anwar, 2015). Mengatasi kesenjangan ini cukup sulit meskipun kenyataannya pemerintah, pemimpin agama progresif, para cendekiawan dan aktivis perempuan memimpin berbagai gerakan egaliter gender yang memandang islam sebagai sumber bagi kemajuan dan keterwakilan perempuan. Pengaruh wasathiyah sangat penting dalam mengatasi kesenjangan gender ini, karena upaya-upaya semacam ini memajukan perempuan sebagai pemeran utama dalam menyuarakan tujuan mereka di daerah mereka. Istilah Al-Wasat (Jalan tengah) dapat dipahami sebagai hubungan yang saling bersinggungan antara laki-laki dan perempuan dalam hal mewujudkan keadilan dan menjadi saksi akan semua ciptaan - Shubada 'ala jami' al-khaliqat (Anwar, 2015).

Konsep wasathiyah sebagai kerangka etika mengejar kesetaraan gender dan mengatasi praktik-praktik yang menindas perempuan. Upaya semacam itu akan berdampak pada komunitas muslim baik secara individual maupun secara sosial. Istilah wasatiyyah menyiratkan bahwa lakilaki dan perempuan harus bersikap moderat dalam berperilaku, memilih dan pengiabdian religious mereka. Dengan pemikiran semacam ini, membangun komunitas yang adil dan inklusif hanya memerlukan pembiasaan akan perbuatan baik, kesalehan dan peran serta seluruh anggota masyarakat.

Perubahan Arab Saudi menjadi negara yang pro kesetaraan gender bermula dari Raja Abdullah menunjuk seorang perempuan untuk diangkat sebagai Wakil Menteri Pendidikan pada 
bulan Februari 2009. Pengangkatan perempuan menjadi pejabat pemerintahan secara tidak langsung mendefinisikan ulang peran gender yang terbentuk dalam masyarakat Arab Saudi yang sangat patriarki ini. Dengan masuknya perempuan ke dalam pemerintahan, membuat peran gender yang terbentuk dalam masyarakat Arab Saudi berubah dari yang awalnya peran laki-laki dan perempuan sangatlah tersegmen dengan laki-laki sebagai pencari nafkah. Perempuan pun menjadi masyarakat kelas dua karena hanya berperan dalam mengurus rumah tangga dengan hakhaknya yang dibatasi.

Sebelumnya pada tahun 2010 lalu Perserikatan Bangsa-Bangsa atau PBB sempat membuat program UN Women. Program UN Women ini dibuat untuk meningkatkan kesetaraan gender dan pemberdayaan perempuan. PBB menciptakan organisasi yang fokus pada kesetaraan gender dan pemberdayaan perempuan yaitu United Nations Women (UN Women) pada 2 Juli 2010. Tujuan dibentuknya organisasi sebagai sarana percepatan tercapainya kesetaraan gender dan pemberdayaan perempuan sebagai bagian dari agenda reformasi PBB yang memiliki empat fokus kesetaraan perempuan (UN Women, n.d.). Pertama perempuan memimpin, dalam partisipasi dan manfaat sama dalam system pemerintahan. Kedua perempuan punya jaminan pendapatan, pekerjaan layak serta otonomi secara ekonomi. Ketiga, terbebasnya perempuan dan anak perempuan dari semua bentuk kekerasan. Keempat, perempuan dan anak perempuan memiliki manfaat yang sama dalam kontribusi dan pengaruh dalam membangun perdamaian dan ketahanan.

Munculnya program UN Women ini merupakan bagian dari reformasi PBB. Upaya PBB untuk meningkatkan program kesetaraan dan pemberdayaan gender melalui UN Women ini berfokus untuk merubah sistem PBB yang sebelumnya. UN Women ini dilaksanakan sebagai divisi yang digunakan untuk memajukan perempuan, mengadakan suatu organisasi atau pelatihan internasional tentang kemajuan perempuan, membuat kantor tentang kesetaraan gender yang didalamnya mengusung nasihat-nasihat isu gender, dan membuat dana pembangunan yang dilakukan dari anggota-anggota PBB.

Munculnya program UN Women ini dilatar belakangi dari tanggapan Sekretaris Jenderal PBB terhadap resolusi Majelis umum PBB 63/311 (UN, 2009). Pada bulan januari 2006 sekretaris jenderal PBB ini mempresentasikan laporan A/64/588 yang didalamnya terdapat proposal yang berjudul "Proposal Komprehsif Badan Majemuk untuk Kesetaraan Gender dan Pemberdayaan Perempuan". Dalam proposalnya yang berupaya untuk meningkatkan kesadaran tentang kesetaraan gender dan pemberdayaan perempuan ini sekretaris jenderal menjelaskan laporannya dan mengungkapkan agar sistem badan anggota PBB yang lainnya turut berkontribusi dalam peningkatan kesetaraan dan pemberdayaan dalam program UN Women ini. Dan diharapkan sistem anggota PBB mampu berusaha untuk mempertajam fokus dan dampak dari kegiatan peningkatan dan pemberdayaan kesetaraan gender dari seluruh sistem anggota PBB.

Selanjutnya mulai terjadi perubahan di Arab Saudi yaitu diawali dengan diangkatnya wakil menteri pendidikan perempuan yang pertama kali pada tahun 2009. Pada tahun 2013 keterbukaan hak politik bagi wanita mulai terbuka sengan diangkatnya 30 orang wanita yang duduk di Dewan Syura Arab Saudi yang sebagian besar berasal dari akademisi dan aktivis (Beritasatu.com, 2013). Sejak tahun 2011 sudah mulai ada gerakan dari para aktivis perempuan di Arab Saudi pada masa raja Abdullah, puncaknya terjadi pada tahun 2015-2018 sebagai dampak opresi gender yang terjadi cukup lama. Aktivis perempuan di Arab Saudi banyak melakukan 
kegiatan kampanye yang banyak dilakukan melalui kampanye virtual. Gerakan tersebut mendapat simpati aktivis Hak Asasi Manusia di dunia internasional. Gerakan mereka menuntut pada pemenuhan hak - hak sipil seperti kebebasan individu yang kemudian diwujudkan dalam pencabutan larangan mengemudi serta hak partisipasi politik pada pemilu 2015 serta penghapusan larangan mengemudi pada perempuan di tahun 2017.

Kebijakan pro kesetaraan gender kemudian bermunculan setelah program Visi Saudi 2030 dicanangkan oleh Mohammad bin Salman. Kebijakan Arab Saudi yang dikenal dunia karena sangat membatasi perempuan, satu per satu dicabut. Kebijakan tidak pro kesetaraan gender pertama yang dicabut adalah larangan perempuan dalam mengendarai mobil. Pemerintah Arab Saudi mulai mengizinkan kembali perempuan-perempuan Arab Saudi untuk mengendarai mobil pada 24 Juni 2018. Jalan yang dilalui agar perempuan di Arab Saudi dapat menyetir kembali sangatlah terjal karena dalam proses penyuaraan kebijakan ini, banyak perempuan yang menjadi korban. Pemerintah Arab Saudi sebelum resmi mengizinkan kembali wanita untuk menyetir sempat menangkap 8 wanita pegiat yang menyuarakan wanita untuk bisa mengemudi kembali. Mereka ditangkap dengan alasan bekerjasama dengan pihak asing. Penolakan juga muncul dari kaum laki-laki yang menyuarakan penolakan ini melalui media sosial. Hal ini menunjukkan bahwa budaya patriarki Arab Saudi masih begitu kuat meskipun Arab Saudi tengah berbenah menjadi negara yang pro dengan kesetaraan gender.

Sebelum kebijakan yang mengizinkan kembali perempuan untuk mengemudi mobil, Arab Saudi telah mengizinkan perempuan untuk menonton pertandingan sepakbola secara langsung di dalam stadion, hal yang sebelumnya dilarang oleh pemerintah Arab Saudi. Kebijakan ini sudah dicanangkan sebelumnya pada tahun 2017 melalui Royal decree no. M/85 tahun 2017 tentang pencabutan larangan mengemudi bagi perempuan dan terealisasi pada tanggal 12 Januari 2018 (Kompas, 2017). Diperbolehkannya perempuan untuk masuk ke dalam stadion ini dibarengi dengan peningkatan fasilitas di stadion yang awalnya hanya disediakan toilet untuk lakilaki di stadion, sekarang terdapat toilet untuk perempuan. Untuk mengakomodir perempuan yang diperbolehkan kembali menonton pertandingan sepakbola secara langsung di dalam stadion, pemerintah Arab Saudi menyiapkan "bagian keluarga" di dalam stadion yang diperuntukkan untuk perempuan (CNNIndonesia, 2018).

Kebijakan pro kesetaraan gender yang diterapkan Arab Saudi selanjutnya adalah memperbolehkan perempuan untuk berpergian ke luar negeri tanpa wali. Hal ini bisa terwujud dikarenakan pemerintah Arab Saudi mengubah sistem perwalian yang telah berlaku lama di Arab Saudi. Reformasi ini mengubah sistem perwalian terbatas yang mengekang kaum perempuan yang telah lama berlaku di Arab Saudi. Sistem perwalian terbatas ini sendiri menjadikan perempuan harus memerlukan izin tertulis dari walinya yang merupakan ayah, suami atau kerabat laki-lakinya. Reformasi ini bisa terjadi tak lepas dari peran aktivis yang getol menyuarakan penghapusan sistem perwalian. Perubahan sistem perwalian ini membuat perempuan di Arab Saudi memperoleh hak atas diri mereka sendiri. Selain bebas berpergian, perempuan di Arab Saudi juga secara resmi memperoleh hak untuk mendaftarkan kelahiran, perkawinan atau perceraian dan diakui sebagai wali bagi anak-anak di bawah umur.

Reformasi sistem perwalian di Arab Saudi merupakan lompatan terbesar bagi perubahan Arab Saudi yang awalnya sangat konservatif menjadi pro kesetaraan gender. Reformasi sistem perwalian ini membuat perempuan dapat bergerak secara otonom untuk 
menggapai impian mereka, sesuatu yang sulit dilakukan oleh perempuan Arab Saudi sebelumnya karena sistem perwalian ini sangat membatasi pergerakan para perempuan di sana. Dengan reformasi sistem perubahan ini, banyak hal positif yang dapat diperoleh perempuan Arab Saudi untuk menggapai impiannya. Diperbolehkannya perempuan untuk berpergian ke luar negeri berarti terbukanya peluang mereka untuk studi ke luar negeri atau bahkan bekerja di luar negeri. Hal ini sebelumnya mustahil untuk dilakukan karena sistem perwalian lama membuat wanita tidak bisa bebas berpergian jika wali mereka tidak mengizinkan.

Semua kebijakan pro kesetaraan gender yang telah dibahas sebelumnya mengerucut pada satu program ambisius yang dicanangkan oleh Putra Mahkota Arab Saudi, Mohammad bin Salman, yaitu Visi Saudi 2030. Secara garis besar, visi ini adalah rencana Arab Saudi untuk melepaskan ketergantungan terhadap minyak bumi dan melakukan diversifikasi ekonomi untuk memperkuat kegiatan ekonomi dan investasi di Arab Saudi, meningkatkan perdagangan di sektor selain minyak dan meningkatkan manufaktur serta alutsista. Selain dalam sektor ekonomi, Visi Saudi 2030 juga menitikberatkan pada revolusi sosial di Arab Saudi. Revolusi sosial ini berfokus pada peningkatan partisipasi perempuan, terutama dalam meningkatkan partisipasi kerja kaum perempuan di Arab Saudi dari yang awalnya 22\% menjadi 30\% (Republika, 2019). Beberapa pembaruan yang terkandung di dalam Visi 2030 yang digagas oleh Mohammad bin Salman antara lain yaitu(Rosida, 2018) pertama, adanya usaha reformasi terhadap kebijakan tradisional dan pengaruh nilai patriarkhi yang kental. Kedua, seolah-olah ingin merubah pola kepemimpinan raja-raja sebelumnya yang fokus pada investasi politik dan mengurangi masalah sumber minyak. Ketiga, berkonsentrasi pada kebijakan dalam satu tangan pada menteri ekonomi.

Revolusi sosial dalam Visi Saudi 2030 ini terinspirasi dari situasi Arab Saudi itu sendiri pada masa 1960 sampai 1970-an dimana pada saat itu efek dari globalisasi masuk ke Arab Saudi sehingga memunculkan liberalisasi di Arab Saudi. Arab Saudi ingin menghapus stigma ultrakonservatif mereka di dunia internasional dengan revolusi sosial yang menitikberatkan pada pengembalian hak-hak perempuan yang dibatasi. Arab Saudi ingin dunia memandang mereka sebagai negara Islam moderat yang terbuka bagi dunia dan seluruh agama. Dengan perubahan stigma dunia terhadap Arab Saudi, Arab Saudi mengharapkan akan masuknya investasi dari luar ke Arab Saudi dan Arab Saudi sendiri juga bisa bebas berinvestasi di berbagai negara tanpa terstigma sebagai negara yang ultrakonservatif.

Arab Saudi berusaha melonggarkan sistem patriarki dalam kehidupan bernegara maupun dalam kehidupan sehari-hari. Penghapusan pembatasan-pembatasan terhadap perempuan ini dinilai memunculkan rasa nyaman di dalam Arab Saudi, meskipun memang masih ada penolakan-penolakan yang muncul dari kaum patriarki. Hal ini sejalan dengan pendekatan feminism liberal yang punya tujuan utama yaitu kesetaraan hak dan kebebasan individu. Hal ini sejalan dengan kebijakan agenda Mohammed bin Salman pada Visi 2030 Arab Saudi serta pandangan politiknya yang sesuai kesetaraan gender.

\section{Kesimpulan}

Arab Saudi merupakan negara yang menganut sistem hukum yang berdasarkan paham salafush shalih yang bermazhab Hambali. Di Arab Saudi kesadaran akan peningkatan keseteraan gender terhadap perempuan sangat kurang. Di Arab Saudi gerak perempuan sangat dibatasi, 
mulai dari konteks pendidikan, sosial, dan politik. Perempuan dan laki-laki di Arab Saudi tidak mempunyai hak yang sama. Perempuan di Arab Saudi juga sering mengalami sebuah diskriminasi. Salah satu aturan yang menimbulkan kontroversial di dalam wilayah Arab Saudi yaitu adanya pelarangan tentang perempuan karir yang mengemudi dan pelarangan perempuan berpergian sendiri. Di Arab Saudi mengharamkan perempuan yang mengemudi mobil. Aturan ini dilakukan berdasarakan hukum syariat yang ada di Arab Saudi.

Selanjutnya Arab Saudi mulai membuat kebijakan tentang pro kesetaraan gender, yang ditandai dengan adanya kebijakan perizinan terhadap perempuan untuk mengemudi dan adanya seorang perempuan di Arab Saudi yang diangkat menjadi pejabat pemerintahan. Hal ini secara tidak langsung mendefinisikan ulang peran gender yang terbentuk dalam masyarakat Arab Saudi. Dengan seiring berjalannya waktu akhirnya Arab Saudi mengeluarkan kebijakan-kebijakan tentang peningkatan kesetaraan dan pemberdayaan perempuan yang diusulkan oleh putra mahkota Arab Saudi, yaitu Mohammad bin Salman dalam program visinya pada tahun 2030.

\section{Daftar Pustaka}

Alarabiya. (2010). Nusus al-ikhtilat sahiha wa min khalifuni yuridu tadlil al-nas. Alarabiya.net. albarrak. (2010). Tahthir min fitna al-da'wa ila al-ikhtilat. Albarrak.islamlight,net. Retrieved from http://albarrak.islamlight.net/index.php?optio n=content\&task=view\&id=17426.

Alwedinani, J. (2016). Gender and Subject Choice in Higher Education in Saudi Arabia. United Kingdom: University of York.

Anwar, E. (2015). The Ethics of Wasatiyah and the Pursuit of Gender Equality. In American Journal of Islamic Social Sciences (Vol. 32). International Institute of Islamic Thought (IIIT).

Ardiansyah. (2013). Pengaruh Mazhab Hanbali dan Pemikiran Ibnu Taimiyah dalam Paham Salafi. Analytica Islamica, 2(2).

Beritasatu.com. (2013, February 20). Dilantik, 30 Wanita Anggota Dewan Syura. Beritasatu.com. Retrieved from https://www.beritasatu.com/asia/97974-dilantik-30-wanita-anggotadewan-syura-arab-saudi.html

CNNIndonesia. (2018, January 12). Kini, Wanita Saudi Boleh Menonton Sepak Bola di Stadion. Cnnindonesia.com.

Retrieved from https://www.cnnindonesia.com/internasional/20180112172729-120-268481/kiniwanita-saudi-boleh-menonton-sepak-bola-di-stadion

Creswell, J. W. (2012). Educational Research. New York: Pearson.

Faktualnews. (2020). Perempuan Arab Saudi dari Waktu ke Waktu. Faktualnews.com. Retrieved from https:// faktualnews.co/2020/01/04/perempuan-arab-saudi-dari-waktu-kewaktu/185610/

Hodgett, D. J., \& Stolte, O. M. E. (2012). Case-based Research in Community and social pychology: Introduction to the special issue. Journal of Community \& Applied Social, 22.

Kompas. (2017, September 27). Akhirnya Arab Saudi Cabut Larangan Mengemudi bagi Perempuan. Kompas.com. Retrieved from https://internasional.kompas.com/read/2017/09/27/14051701/akhirnya-arab-saudicabut-larangan-mengemudi-bagi-perempuan

Kompas. (2019, October 7). "Putra Mahkota MBS, Sosok Kunci Dalam Reformasi Arab Saudi." Kompas.com. Retrieved from https://internasional.kompas.com/read/2019/10/07/16163441/putra-mahkota-mbssosok-kunci-dalam-reformasi-arab-saudi?page $=$ all

Lilolia, A. (2019). Perempuan Arab Saudi sedang berjuang untuk kebebasan - dan kesuksesan mereka terus bertambah. Retrieved from https://theconversation.com/perempuan-arab-saudi-sedang- 
berjuang-untuk-kebebasan-dan-kesuksesan-mereka-terus-bertambah-122269

Maslamah, \& Muzani, S. (2014). Konsep-Konsep Gender Dalam Pespektif Islam. SAWWA, $9(2)$.

Meijer, R. (n.d.). Reform in Saudi Arabia: The Gender-Segregation Debate. Middle East Policy Council, 4(xvii). Retrieved from https://mepc.org/reform-saudi-arabia-gendersegregation-debate

Nuryatno, A. (2001). Islam, Teologi Pembebasan Dan Kesetaraan Gender (Studi Atas Pemikiran Ashgar Ali Engineer) (M. Shobirin, Ed.). Yogyakarta: UII Press.

Qodarsasi, U. (2014). Penyelesaian Kasus Kekerasan Terhadap Tenaga Kerja Wanita Indonesia di Malaysia Melalui Implementasi Konvensi CEDAW PBB 1979. Palastren, 7(1), 169_ 192.

Republika. (2013, November 23). Kenapa Muslimah Arab Saudi Dilarang Menyetir? Republika.co.id. Retrieved from https://www.republika.co.id/berita/duniaislam/fatwa/13/11/23/mwplcw-kenapa-muslimah-arab-saudi-dilarang-menyetir

Republika. (2019, March 19). "Wajah Saudi Era 60-an, Masa Keterbukaan Untuk Perempuan." Republika.com. Retrieved from https://www.republika.co.id/berita/duniaislam/dunia/polnpj320/wajah-saudi-era-60an-masa-keterbukaan-untuk-perempuan.

Rohim, N. (2013). Kedudukan Konstitusi dalam Praktik Ketatanegaraan Saudi Arabia. Tabkim, IX(2).

Rosida, A. (2018). Wacana Modernisasi Dalam Tantangan Peradaban, Peran Perempuan Sebagai Tonggak Sejarah Arab Saudi. Jurnal Palita, 3(1).

statistica. (n.d.). Saudi Arabia has Become the World Biggest Arms Importer. Retrieved from https://www.statista.com/chart/3295/saudi-arabia-has-become-the-worlds-biggestarms-importer/

UN. (2009). UN Women "Resolution 63/311 General Assembly." Retrieved from https://undocs.org/A/res/63/311

UNDP. (2019). Inequalities in Human Development in the 21st Century Briefing note for countries on the 2019 Human Development Report. Retrieved from http://hdr.undp.org/sites/all/themes/hdr_theme/country-notes/SAU.pdf 